\title{
An examination of clinical differences between carriers and non-carriers of chromosome 8q24 risk alleles in a New Zealand Caucasian population with prostate cancer
}

Karen S Bishop, Dug Yeo Han, Nishi Karunasinghe, Megan Goudie, Jonathan G Masters, Lynnette R Ferguson

Background: Prostate cancer makes up approximately $15 \%$ of all cancers diagnosed in men in developed nations and approximately $4 \%$ of cases in developing nations. Although it is clear that prostate cancer has a genetic component and single nucleotide polymorphisms (SNPs) can contribute to prostate cancer risk, detecting associations is difficult in multi-factorial diseases, as environmental and lifestyle factors also play a role. In this study, specific clinical characteristics, environmental factors and genetic risk factors were assessed for interaction with prostate cancer. Methods: 489 prostate cancer cases and 427 healthy controls were genotyped for SNPs found on chromosome 8q24 and a genetic risk score was calculated. In addition the SNPs were tested for an association with a number of clinical and environmental factors. Results: Age and tobacco use were positively, whilst alcohol consumption was negatively associated with prostate cancer risk. The following SNPs found on chromosome 8q24 were statistically significantly associated with prostate cancer: rs10086908, rs16901979; rs1447295 and rs4242382. No association between Gleason score and smoking status, or between Gleason score and genotype were detected. Conclusion: A genetic risk score was calculated based on the 15 SNPs tested and found to be significantly associated with prostate cancer risk. Smoking significantly contributed to the risk of developing prostate cancer, and this risk was further increased by the presence of four SNPs in the $8 q 24$ chromosomal region. 
1 An examination of clinical differences between carriers and non-carriers of chromosome

28 824 risk alleles in a New Zealand Caucasian population with prostate cancer.

3 Karen S. Bishop*1, Dug Yeo Han ${ }^{2,3}$, Nishi Karunasinghe ${ }^{1}$, Megan Goudie ${ }^{4}$, Jonathan G. Masters ${ }^{4}$

4 and Lynnette R. Ferguson ${ }^{1,2,3}$.

$5 \quad{ }^{1}$ Auckland Cancer Society Research Centre, Faculty of Medical and Health Sciences, University

6 of Auckland, Auckland, New Zealand.

$7 \quad{ }^{2}$ Discipline of Nutrition, FM\&HS, University of Auckland, Auckland, New Zealand.

$8 \quad{ }^{3}$ Nutrigenomics New Zealand, New Zealand.

$9 \quad{ }^{4}$ Urology Department, Auckland Hospital, New Zealand.

10 *Correspondence should be addressed to Karen Bishop; Auckland Cancer Society Research

11 Centre; Bld 504 Rm 016; University of Auckland; Private Bag 92019; Auckland; 1142; New

12 Zealand; Telephone number: +649 9234471. Fax number: +64 9 3737502. Email address:

13 k.bishop@auckland.ac.nz 
Abstract:

17 Background: Prostate cancer makes up approximately $15 \%$ of all cancers diagnosed in men in developed nations and approximately $4 \%$ of cases in developing nations. Although it is clear that prostate cancer has a genetic component and single nucleotide polymorphisms (SNPs) can contribute to prostate cancer risk, detecting associations is difficult in multi-factorial diseases, as environmental and lifestyle factors also play a role. In this study, specific clinical characteristics, environmental factors and genetic risk factors were assessed for interaction with prostate cancer. Methods: 489 prostate cancer cases and 427 healthy controls were genotyped for SNPs found on chromosome 8q24 and a genetic risk score was calculated. In addition the SNPs were tested for an association with a number of clinical and environmental factors. Results: Age and tobacco use were positively, whilst alcohol consumption was negatively associated with prostate cancer risk. The following SNPs found on chromosome $8 \mathrm{q} 24$ were statistically significantly associated with prostate cancer: rs10086908, rs16901979; rs1447295 and rs4242382. No association between Gleason score and smoking status, or between Gleason score and genotype were detected. Conclusion: A genetic risk score was calculated based on the 15 SNPs tested and found to be significantly associated with prostate cancer risk. Smoking significantly contributed to the risk of developing prostate cancer, and this risk was further increased by the presence of 33 four SNPs in the 8q24 chromosomal region. 


\section{Introduction}

Population differences in cancer incidence may reflect differences in genotype and intake of, or exposure to cancer promoting or preventative factors. Identification of genetic risk factors for cancer often utilises linkage studies in high-risk families, but this approach has proved difficult when applied to prostate cancer due to interacting lifestyle and environmental factors (Crawford, 2003; Xu et al., 2013). The only clearly established risk factors for prostate cancer are increasing age, family history of prostate cancer and ethnicity (Crawford, 2003; Nordström et al., 2013; Sun et al., 2011), although adoption of a Western diet, increased life expectancy and PSA testing are thought to contribute to the rise in detection of prostate cancer in Asian countries (Xu et al., 2013).

Although there is evidence for a significant hereditary component of prostate cancer susceptibility, results are inconsistently replicated. A positive family history of prostate cancer is associated with increased risk, but relative risk (RR) ratios vary from one study to the next (Goh et al., 2012). Twin studies have been used to reveal the heritability of prostate cancer and values have ranged from 0.36 to 0.57 (Ahlbom et al., 1997; Lichtenstein et al., 2000; Neale et al., 2005; Page et al., 1997) leaving no doubt regarding a strong genetic component. In addition, in a review of genetic association studies, Xu et al (Goh et al., 2012; Xu et al., 2013)] concluded that RR of prostate cancer was highest if a primary relative, particularly a brother, was diagnosed with prostate cancer before the age of 60 years.

In numerous studies the association between single nucleotide polymorphisms (SNPs) in the 8 q24 region and prostate cancer, have been reported (Amundadottir et al., 2006; Gudmundsson et al., 2007; Wang et al., 2011). For example the A allele of SNP rs1447295 was associated with an increased prostate cancer risk in Japanese, Native, Latino, African and European Americans 
58 (Freedman et al., 2006; Gudmundsson et al., 2007; Severi et al., 2007). However, reports on this

59 SNP explain only a portion of the signal described (Amundadottir et al., 2006), and fail to

60 account for all of the heritability. Of the five haplotype blocks (on 8q24) associated with various

61 cancers, three solely and independently contribute to prostate cancer risk (Ghoussaini et al., 62 2008b).

63 Clinical characteristics play an important role in the selection of appropriate treatment and 64 prognosis for prostate cancer (Heidenreich et al., 2014). However, it is likely that clinical 65 characteristics interact with environmental and genetic risk factors to determine risk of prostate 66 cancer progression. The environmental factors that have been identified as playing a possible 67 role in the development or progression of prostate cancer include various aspects of dietary 68 intake, alcohol consumption, tobacco use, physical activity levels and energy balance, although 69 evidence is inconsistent (Wolk, 2009; Xu et al., 2013). However, it is difficult to clearly 70 delineate risk due to the influence of confounding factors as it is difficult or impossible to control 71 the effect of numerous variables and thus tease out the impact of individual factors. However, an 72 individual's genes, physiological state and environmental exposures must be considered when 73 assessing disease risk and recommending treatment and lifestyle interventions (Davis and 74 Milner, 2007).

75 SNPs found in 8q24 regions 1-3 and thought to be associated with prostate cancer risk will be 76 examined in this study and tested for interactions with clinical and environmental factors in a 77 New Zealand population.

\section{Materials and Methods}


80 A retrospective case-control, population-based study was performed to explore the association

81 between $8 \mathrm{q} 24$ genotypes and the clinical manifestations of prostate cancer.

82 A total of 916 male participants (489 with prostate cancer and 427 healthy controls) were

83 recruited from Auckland, New Zealand (NZ) between 2006 and 2014. The study was more than

84 adequately powered based on calculations carried out prior to recruitment on expected GPXI

85 allele frequency (24 volunteers were required for each group based on a difference in allele

86 frequency of 0.058 , significance $=0.05 \%$ and power $=80 \%$ ). Only those who self-reported as

87 having European ancestry were included in this analysis. Due to very small numbers, and

88 therefore low statistical power, it was decided not to analyse data from other ethnic groups.

89 Control participants were a group with no known cancers at recruitment (with the exception of

90 skin cancers). The volunteers were recruited with written informed consent and formed part of

91 either the Urology Study or the Selenium Supplementation Study carried out by the Auckland

92 Cancer Society Research Centre, University of Auckland after receiving approval of the study

93 from the Health and Disabilities Ethics Committees: Northern Y Regional Ethics Committee,

94 NZ, (Ethics Ref: NTY/06/07/060 and NTY/05/06/037). Men with prostate cancer who met the

95 study requirements were selected from the databases from the Auckland Regional Urology

96 facility. This database incorporated the Auckland District Health Board, Counties Manukau

97 District Health Board, Waitemata District Health Board and private practices within the

98 Auckland region. Hardcopy invitations were sent to all eligible men with an approximately $25 \%$

99 response rate. Among the Selenium Supplementation Study participants, only those who

100 consented to the use of their blood samples for future NZ Ethics Committee accredited studies

101 were used in this analysis. The following data were collected and analysed: date of birth, height,

102 weight, chronic medication, smoking status, family history of cancer, diagnostic PSA and 
103 Gleason score (where relevant). Data were collected at the time of enrolment. For the prostate 104 cancer group, enrolment initially took place within 12 months of diagnosis $(60.2 \%$ of those 105 enrolled) and thereafter enrolment criteria were modified such that diagnosis could have taken 106 place at any time prior to enrolment. Gleason scores were obtained from biopsy histopathology 107 unless participants underwent a prostatectomy, in which case the post-surgical Gleason score 108 was used. Alcohol consumption was categorised as "Yes" or "No" such that "Yes" applied to 109 anyone who consumed one or more alcoholic units per week over the past year. Smoking was 110 categorised as "never" or "ever" smoked. "Ever" smoked presented both "present" and "former" 111 smokers, as there was insufficient power to analyse "present" smokers on their own. The study 112 investigators were not blinded to group allocation.

113 Blood collection and processing: Blood samples were collected into EDTA vaccutainer tubes 114 (Becton Dickinson, Plymouth, England) from study participants at enrolment. Total genomic 115 DNA extraction was carried out with the QIAamp DNA Blood Mini Kit (Qiagen, Hilden, 116 Germany). A fully automated procedure on the QIAcube (Qiagen) was followed according to the 117 manufacturer's recommendations. DNA was quantified and checked for purity using a Nanodrop 118 ND1000 (Thermo Fisher Scientific, USA), stored at $-20^{\circ} \mathrm{C}$ and used for genotyping at a 119 concentration of $10 \mathrm{ng} / \mu 1$.

120 Genotyping: SNPs were selected based on results from a literature search targeting SNPs that are 121 associated with prostate cancer and found on chromosome 8q24 (Al Olama et al., 2009b; 122 Ghoussaini et al., 2008b; Gudmundsson et al., 2009; Gudmundsson et al., 2007; Pal et al., 2009). 123 None of the SNPs at the time of selection were known to be in LD with each other, and SNPs 124 subsequently found to be in LD were removed from the analysis. Genotyping was performed 125 using a Sequenom MassArray system (Sequenom, San Diego, CA, USA). The products were 
126 spotted and fired and run on a MALDI-TOF mass spectrometer. The quality of the genotyping

127 was assessed by checking the results from CEU HapMap samples $(n=6)$ and comparing them

128 with SNP data available on the HapMap Genome Browser release \#28, build

129 \#37.3(http://hapmap.ncbi.nlm.nih.gov), as well as by comparing results from duplicate samples.

130 SNP data are deposited in the Figshare repository

131 figshare.com/s/750929b0829d11e583c306ec4bbcf141 (This data will be made public upon acceptance of

132 this manuscript for publication)

133 Genetic Risk Score (GRS): A GRS was calculated in order to evaluate the accumulative effects

134 of all the 8q24 SNPs tested. A weighted GRS was created by using 15 SNPs assessed in this

135 study (Table 1) (De Jager et al., 2009). Firstly, the weight value of each SNP was calculated by

136 using the natural log of the published odds ratios and assigning the weight value of each SNP

137 made up to a total of $100 \%$. Secondly, the weighted GRS (named wGRS15 in this study) was

138 calculated by multiplying the weighted value of the SNP by the number of the tested allele of the

139 SNP for each participant. Thirdly, these values were then summed across all of the 15 SNPs (De

140 Jager et al., 2009).

141 Statistical Analysis: The outcome of interest, namely recorded pathology was fitted for

142 association with 15 candidate SNPs found on chromosome 8q24. Four phenotypic variables

143 (smoking status, alcohol consumption, age at diagnosis/joining the study, and body mass index

144 (BMI)) were tested with the outcomes of interest using a multivariate analysis and squared data.

145 Smoking status, alcohol consumption, and age at diagnosis (cases) were significantly associated 146 with histology and hence these variables were adjusted for prior to further analyses. A 147 generalised linear model was fitted to test the linearity of the genotype-phenotype relationship. 
148 For linearity of the genotype-phenotype relationship, an additive model was used whereby each

149 SNP was coded 0, 1, and 2 (Balding, 2006).

150 All analyses were corrected for multiple testing using a false discovery rate (FDR) (Storey, 151 2002). SAS (V9.2 SAS Institute., Cary, NC, USA) and R (Computing, 2012) were used for 152 statistical analyses.

\section{3. Results}

154 The control group comprised of healthy men with no history of cancer (excluding melanoma) 155 and a PSA below 4ng/ml. The control group was significantly younger (mean age $=53.1$ years) 156 than the men with prostate cancer (mean age 65.8 years). Within five years of enrolment 9 men 157 from the control group had developed prostate cancer and were enrolled as volunteers on the 158 Urology study. Tumour staging data were not used as less than $50 \%$ of the data were available. 159 Gleason scores ranged from 4 to 10 with $36 \%$ of volunteers with a Gleason score of 6 or less, $16045 \%$ with a Gleason score of 7 and $20 \%$ with a Gleason score of 8 or greater.

161 Smoking status was tested for association with prostate cancer (Table 2), and there were 162 significantly more "Ever" smoked among those with prostate cancer compared to controls, with 163 an odds ratio (OR) of 2.28 (95\% CI 1.62-3.21). An OR of 0.57 (95\% CI $0.37-0.90)$ was associated with alcohol consumption, indicating that fewer men with prostate cancer drank one or more alcoholic units per week, than healthy men. After performing a multivariate analysis it was found that as healthy men age, they tend to drink less, whereas men with prostate cancer drink comparatively more than healthy men of a similar age $(p=3.24$ e- 07$)$. In contrast, older men who smoked were more likely to have prostate cancer than those who never smoked $(p=4.63$ e14). No significant association was found between BMI and prostate cancer. Smoking status, 170 alcohol consumption and age of diagnosis were adjusted for further genotypic analysis SNP 
171 locations are shown in Figure 1 and Table 3. A risk assessment on malignancy in association

172 with the SNPs is shown in Table 4. Rs16901979 and rs6983561 were both found to be in strong

$173 \operatorname{LD}\left(D^{\prime}=0.999, p=2.22\right.$ e-16). For this reason rs6983561 was removed from all analyses. Four

174 polymorphisms (rs10086908 [ $T$ allele], rs16901979 [ $A$ allele], rs1447295 $[A$ allele] and

175 rs4242682 [A allele]) showed an increased risk of prostate cancer compared to the controls

176 before and after adjustment for confounding variables, and remained significant after applying an

177 FDR.

178 The wGRS15 and histology were significantly associated (Table 4) and graphically shown in

179 Figure 2. As the influence of the risk alleles on prostate cancer increases there is greater variance

180 between the prostate cancer cases and healthy controls (Figure 2).

181 4. Discussion

182 In a Caucasian population residing in NZ we evaluated clinical characteristics as well as 15 SNPs

183 located in the 8q24 chromosomal region that may independently confer susceptibility to prostate

184 cancer. The search for genetic and lifestyle risk factors for prostate cancer is challenging due to

185 varying results from different populations throughout the world and the need to and difficulty

186 associated with controlling for numerous variables. The results presented here help to answer the

187 question regarding the impact of BMI, age, smoking and alcohol intake, as well as polymorphisms

188 in $8 \mathrm{q} 24$, on the risk of developing prostate cancer.

189 Numerous genome wide association studies have been carried out in large case-control studies in

190 order to identify SNPs with small effects on prostate cancer risk and progression. Over 80 common

191 SNPs have been estimated to contribute to prostate cancer risk (Han et al., 2015) and 33\% of

192 familial risk is associated with known SNPs (Al Olama et al., 2014). Although in many cases the 
193 contribution to genetic risk and interaction with treatment type is understood, the interaction with 194 environmental influences remains to be elucidated (Eeles et al., 2014).

195 One of the problems associated with comparing results of studies carried out in different 196 countries (with differing PSA testing policies) and in different communities, with varying 197 degrees of uptake of available medical services, is that men in the different studies are diagnosed 198 at a different stage of prostate cancer. PSA is a biomarker that was initially used to monitor 199 response to treatment and since the early 1990's has been used as an indicator for suspicion of 200 asymptomatic prostate disease (Cooner et al., 1990). A problem arises as detection of prostate 201 cancer using PSA as a screening method identifies lesions whose biological behaviour might not 202 be the same as those identified due to clinical symptoms. In a country where a PSA screening 203 programme is in place over a long period of time, one would expect most men to be recruited in 204 the early stages of disease relative to a study carried out where PSA screening is not encouraged.

205 Also, in the former one would expect to enrol more men with prostate cancer that might remain 206 symptomless i.e. men who would die with prostate cancer and not from prostate cancer. NZ does 207 not recommend PSA screening for asymptomatic men but the National Health Committee agree 208 that prostate cancer is a suitable candidate for screening (NHC, 2004) and for example, one in four men over the age of 40 years living in the Waikato District of NZ were tested for PSA in 2102010 (Hodgson et al., 2012). Of these, 71\% were asymptomatic (Hodgson et al., 2012). For this 211 reason one would expect a cohort of NZ men diagnosed with prostate cancer to consist of both 212 early and later stage disease, and this is likely the case if Gleason score is considered as an 213 indicator. Despite the increasing awareness of the risk of prostate cancer and the availability of 214 the PSA test as an indicator of prostate cancer suspicion, those with a Gleason score of 8 or 215 greater comprised $20 \%$ of the cohort, i.e. they were not diagnosed at an early stage of disease. 
216 Numerous studies report no association between smoking and diagnosis of prostate cancer

217 (Giovannucci et al., 2007; Wolk, 2005), although Giovannucci et al (Giovannucci et al., 2007)

218 and others have found that smoking is associated with an increased odds ratio of developing

219 aggressive prostate cancer. In our study smoking tobacco was significantly associated with

220 prostate cancer risk (Table 2.). No association was found between smoking and Gleason score

221 (data not shown). Hereafter smoking was regarded as a confounding variable and adjusted for in

222 further analyses (Table 2).

223 The lack of an association between BMI and prostate cancer incidence or more aggressive

224 disease in our study could reflect the real lack of an association or it could be due to the inability

225 of this study to adequately address this question. BMI was calculated at the time of enrolment,

226 which varied from within 3 months to 8 years since diagnosis. However, just over $60 \%$ of

227 volunteers with prostate cancer were enrolled within 12 months of diagnosis. BMI may have

228 fluctuated over the lifespan and may also have changed since diagnosis and hence the 229 measurement obtained may not reflect the BMI that influenced prostate cancer incidence. A

230 cancer diagnosis sometimes evokes questions regarding causality, and some of our study

231 participants self-reported a change in lifestyle with respect to smoking status, alcohol

232 consumption, exercise and/or diet. Some of these lifestyle changes were maintained and were

233 measurable (e.g. smoking cessation), whilst others (such as cooking methods and a decrease in

234 animal fat intake) were not so easy to define and fluctuated over time. In addition to diagnosis,

235 increasing age may influence lifestyle. In this study we know that fewer men with prostate

236 cancer, drank alcohol than men who were healthy, but we also found that this association was

237 confounded by age such that fewer older men with prostate cancer drank alcohol. Although there 
238 is evidence to support the view that alcohol consumption decreases with age, conflicting data

239 also exists (Thomas and Dilip, 1999).

240 In contrast to the negative association between age and alcohol consumption, in this study age

241 was positively associated with ever smoked and prostate cancer, thus supporting the view that

242 risk of prostate cancer increases with age and smoking of tobacco. For this reason it is difficult to

243 analyse the effect of some lifestyle changes on prostate cancer progression retrospectively and

244 the time delay between diagnosis and enrolment is a limitation of this study.

245 Numerous risk loci for prostate cancer have been identified including a number in chromosome

246 8q24 (Amundadottir et al., 2004; Helfand et al., 2010; Kim et al., 2010; Okobia et al., 2011) and

247 we tested 15 SNPs in chromosome 8q24.21 (Table 4) that were thought to contribute to prostate

248 cancer risk, mortality, high Gleason scores or biochemical recurrence. The importance of this

249 region was first implicated in prostate cancer in a genetic linkage analysis in Icelandic families

250 (Amundadottir et al., 2006) and more recently has been proposed as a chromatin regulatory hub

251 (Du et al., 2015). Chromosome aneusomy, including the gain of the 8q24 (MYC) region, has

252 been reported from radical prostatectomy specimens (both carcinoma and adjacent tissues) in

253 those with prostate cancer as well as from 15\% of benign prostatic hyperplasia tissue (Zhang et

254 al., 2014). This indicates that these chromosomal changes may occur in the progression of

255 carcinogenesis in prostate tissue. Evidence for prostate cancer association within the region is

256 particularly strong, with five distinct linkage disequilibrium (LD) blocks, spanning a 440-kb

257 interval on 8q24 harbouring risk variants (Al Olama et al., 2009a; Ghoussaini et al., 2008a).

258 Although chromosome 8q24 is often described as a gene desert (Kastler et al., 2010; Wasserman

259 et al., 2010) there are a number of genes and SNPs in this region that may lead to the

260 development of prostate cancer (Figure 1.) and could collectively play a role as a biomarker. The 
261 closest known gene is $c-M Y C$ (Hawksworth et al., 2010). Other neighbouring genes include the

262 pseudogene POU5F1P1 (Kastler et al., 2010), FAM84B (Ghoussaini et al., 2008b) and PVT1

263 (Meyer et al., 2011) (Figure 1.).

$264 C-M Y C$ has an established role in carcinogenesis and is rearranged in approximately $15 \%$ of 265 multiple myelomas (Glitza et al., 2015). C-MYC functions to regulate cell-cycle differentiation, 266 proliferation and apoptosis (Albihn et al., 2010) and hence it is an attractive candidate for an 267 association with prostate cancer as these are important molecular targets for environmental 268 variables in cancer prevention (Davis and Milner, 2007). C-MYC over-expression in prostate 269 cancer enables androgen-independent growth and is associated with a Gleason score $>5$ (Karan 270 et al., 2002; Yang et al., 2005). However, a number of authors have looked for an association 271 between differences in $c-M Y C$ and miRNA transcription in normal and malignant tissues and 272 8q24 polymorphisms, yet no associations were found (Pomerantz et al., 2009; Ribeiro et al., 273 2007). Despite this, expression of $c-M Y C$ in early prostatic cancer tissues has been shown to be a 274 good indicator for aggressive disease (Hawksworth et al., 2010).

275 The coding sequence for the gene $P O U 5 F 1 B$ is found in region 3 of chromosome 8q24 (also 4 276 exons and 3 transcriptional start sites are found in this region) and it is the only gene in this 277 region with coding capacity. In addition it may play a role in regulating stem cell pluripotency 278 (Nichols et al., 1998) and hence SNPs in this region may lead to prostate cancer susceptibility. 279 Although Kastler et al. (Kastler et al., 2010) found a three-fold higher POU5F1P1 expression in 280 prostate cancer tissue versus surrounding normal tissue, and Pal et al (Pal et al., 2009) have 281 found an association between SNP variants in this region and susceptibility to prostate cancer 282 (and in the case of rs6470517 with aggressive prostate cancer), no association has consistently 283 been made between gene expression and prostate cancer risk variants in 8q24 (Gudmundsson et 
284 al., 2007) or experimental design has not included both expression and risk variants (Kastler et

285 al., 2010; Pal et al., 2009). SNPs that may be associated with POU5F1P1, namely rs1447295 and

286 rs4242383, were found to be significantly associated with prostate cancer both before and after

287 adjustment for confounders and after correction for multiple testing (Tables 2 and 4). Rs 1447295

288 was one of the first variants in this region shown to have a strong association with prostate

289 cancer risk in diverse populations (Amundadottir et al., 2006; Robbins et al., 2007; Yeager et al.,

290 2007) and hence, in this respect, our data is consistent with that obtained by others.

291 Rs16901979 was found to be significantly associated with prostate cancer in this study ). This is

292 in general agreement with the article by Gudmundsson et al where rs16901979 is believed to

293 contribute $2-4 \%$ to the heritability of prostate cancer in Caucasian populations, but a vastly

294 greater percentage of heritability in Negroid populations (Gudmundsson et al., 2007).

295 In addition to the difference in mean age between the cases and controls, a limitation of this

296 study is the lack of a definitive test to confirm that those within the control group did not have

297 prostate cancer. A negative biopsy of the prostate gland would be a suitable criterium for

298 inclusion of volunteers into the control group, but this was not a reasonable expectation.

\section{Conclusion}

301

302

303

304

305

306

Prostate cancer is one of the most common cancers amongst men, yet suitable biomarkers to accurately and reliably identify prostate cancer are not available. In this study both modifiable and non-modifiable risk factors for prostate cancer have been identified. A genetic risk score was calculated based on the 15 SNPs tested and found to be significantly associated with prostate cancer. Smoking and age significantly contributed to the risk of developing prostate cancer, and this risk was further increased by the presence of five SNPs in the $8 \mathrm{q} 24$ chromosomal region. 
307 The results presented here help to answer the question regarding the impact of modifiable risk

308 factors, as well as polymorphisms in $8 \mathrm{q} 24$, on the risk of developing prostate cancer.

309

310

311

312

313

314

315

316

317

318

319

320

321

322

323

324

325

326

327

328

329

330

331

332

333

334

335

336

337

338

339

340

Acknowledgements

The authors thank Tom Manly (AgResearch, NZ) and Philip Shepherd (The Liggins Institute, NZ) for running the Sequenom plates. The volunteers who made this study possible by consenting to participate in this study are acknowledged.

Conflict of interest

The authors declare no conflict of interest.

\section{References}

Ahlbom, A., Lichtenstein, P., Malmström, H., Feychting, M., Pedersen, N. L., Hemminki, K., 1997. Cancer in Twins: Genetic and Nongenetic Familial Risk Factors. Journal of the National Cancer Institute 89, 287293.

Al Olama, A., Kote-Jarai, Z., Giles, G., Guy M, M. J., Severi G, Leongamornlert DA, Tymrakiewicz M, Jhavar S, Saunders E, Hopper JL, Southey MC, Muir KR, English DR, Dearnaley DP, Ardern-Jones AT, Hall AL, O'Brien LT, Wilkinson RA, Sawyer E, Lophatananon A; UK Genetic Prostate Cancer Study Collaborators/British Association of Urological Surgeons' Section of Oncology; UK Prostate testing for cancer and Treatment study (ProtecT Study) Collaborators, Horwich A, Huddart RA, Khoo VS, Parker CC, Woodhouse CJ, Thompson A, Christmas T, Ogden C, Cooper C, Donovan JL, Hamdy FC, Neal DE, Eeles RA, Easton DF., 2009a. Multiple loci on 8q24 associated with prostate cancer susceptibility. Nat Genet. 41, 1058-1060.

Al Olama, A. A., Kote-Jarai, Z., Berndt, S. I., Conti, D. V., Schumacher, F., Han, Y., Benlloch, S., Hazelett, D. J., Wang, Z., Saunders, E., Leongamornlert, D., Lindstrom, S., Jugurnauth-Little, S., Dadaev, T., Tymrakiewicz, M., Stram, D. O., Rand, K., Wan, P., Stram, A., Sheng, X., Pooler, L. C., Park, K., Xia, L., Tyrer, J., Kolonel, L. N., Le Marchand, L., Hoover, R. N., Machiela, M. J., Yeager, M., Burdette, L., Chung, C. C., Hutchinson, A., Yu, K., Goh, C., Ahmed, M., Govindasami, K., Guy, M., Tammela, T. L. J., Auvinen, A., Wahlfors, T., Schleutker, J., Visakorpi, T., Leinonen, K. A., Xu, J., Aly, M., Donovan, J., Travis, R. C., Key, T. J., Siddiq, A., Canzian, F., Khaw, K.-T., Takahashi, A., Kubo, M., Pharoah, P., Pashayan, N., Weischer, M., Nordestgaard, B. G., Nielsen, S. F., Klarskov, P., Roder, M. A., Iversen, P., Thibodeau, S. N., McDonnell, S. K., Schaid, D. J., Stanford, J. L., Kolb, S., Holt, S., Knudsen, B., Coll, A. H., Gapstur, S. M., Diver, W. R., Stevens, V. L., Maier, C., Luedeke, M., Herkommer, K., Rinckleb, A. E., Strom, S. S., Pettaway, C., Yeboah, E. D., Tettey, Y., Biritwum, R. B., Adjei, A. A., Tay, E., Truelove, A., Niwa, S., Chokkalingam, A. P., CannonAlbright, L., Cybulski, C., Wokolorczyk, D., Kluzniak, W., Park, J., Sellers, T., Lin, H.-Y., Isaacs, W. B., Partin, A. W., Brenner, H., Dieffenbach, A. K., Stegmaier, C., Chen, C., Giovannucci, E. L., Ma, J., Stampfer, M., 
341

Penney, K. L., Mucci, L., John, E. M., Ingles, S. A., Kittles, R. A., Murphy, A. B., Pandha, H., Michael, A., Kierzek, A. M., Blot, W., Signorello, L. B., Zheng, W., Albanes, D., Virtamo, J., Weinstein, S., Nemesure, B., Carpten, J., Leske, C., Wu, S.-Y., Hennis, A., Kibel, A. S., Rybicki, B. A., Neslund-Dudas, C., Hsing, A. W., Chu, L., Goodman, P. J., Klein, E. A., Zheng, S. L., Batra, J., Clements, J., Spurdle, A., Teixeira, M. R., Paulo, P., Maia, S., Slavov, C., Kaneva, R., Mitev, V., Witte, J. S., Casey, G., Gillanders, E. M., Seminara, D., Riboli, E., Hamdy, F. C., Coetzee, G. A., Li, Q., Freedman, M. L., Hunter, D. J., Muir, K., Gronberg, H., Neal, D. E., Southey, M., Giles, G. G., Severi, G., The, B., Prostate Cancer Cohort, C., The, P. C., The, C. C., The, G.-O. N. E. C., Cook, M. B., Nakagawa, H., Wiklund, F., Kraft, P., Chanock, S. J., Henderson, B. E., Easton, D. F., Eeles, R. A., Haiman, C. A., 2014. A meta-analysis of 87,040 individuals identifies 23 new susceptibility loci for prostate cancer. Nature Genetics 46, 1103-1109.

Al Olama, A. A., Kote-Jarai, Z., Giles, G. G., Guy, M., Morrison, J., Severi, G., Leongamornlert, D. A., Tymrakiewicz, M., Jhavar, S., Saunders, E., Hopper, J. L., Southey, M. C., Muir, K. R., English, D. R., Dearnaley, D. P., Ardern-Jones, A. T., Hall, A. L., O'Brien, L. T., Wilkinson, R. A., Sawyer, E., Lophatananon, A., Horwich, A., Huddart, R. A., Khoo, V. S., Parker, C. C., Woodhouse, C. J., Thompson, A., Christmas, T., Ogden, C., Cooper, C., Donovan, J. L., Hamdy, F. C., Neal, D. E., Eeles, R. A., Easton, D. F., 2009b. Multiple loci on 8q24 associated with prostate cancer susceptibility. Nature Genetics 41, 1058-1060.

Albihn, A., Johnsen, J. I., Arsenian Henriksson, M., 2010. Chapter 6 - MYC in Oncogenesis and as a Target for Cancer Therapies. In: George, F. V. W., George, K. (Eds.), Advances in Cancer Research, vol. Volume 107. Academic Press, pp. 163-224.

Amundadottir, L. T., Sulem, P., Gudmundsson, J., Helgason, A., Baker, A., Agnarsson, B. A., Sigurdsson, A., Benediktsdottir, K. R., Cazier, J.-B., Sainz, J., Jakobsdottir, M., Kostic, J., Magnusdottir, D. N., Ghosh, S., Agnarsson, K., Birgisdottir, B., Le Roux, L., Olafsdottir, A., Blondal, T., Andresdottir, M., Gretarsdottir, O. S., Bergthorsson, J. T., Gudbjartsson, D., Gylfason, A., Thorleifsson, G., Manolescu, A., Kristjansson, K., Geirsson, G., Isaksson, H., Douglas, J., Johansson, J.-E., Balter, K., Wiklund, F., Montie, J. E., Yu, X., Suarez, B. K., Ober, C., Cooney, K. A., Gronberg, H., Catalona, W. J., Einarsson, G. V., Barkardottir, R. B., Gulcher, J. R., Kong, A., Thorsteinsdottir, U., Stefansson, K., 2006. A common variant associated with prostate cancer in European and African populations. Nature Genetics 38, 652-658.

Amundadottir, L. T., Thorvaldsson, S., Gudbjartsson, D. F., Sulem, P., Kristjansson, K., Arnason, S., Gulcher, J. R., Bjornsson, J., Kong, A., Thorsteinsdottir, U., Stefansson, K., 2004. Cancer as a Complex Phenotype: Pattern of Cancer Distribution within and beyond the Nuclear Family. PLoS Medicine 1, e65. Balding, D. J., 2006. A tutorial on statistical methods for population association studies. Nature Reviews Genetics 7, 781-791.

Computing, R. F. f. S., 2012. R: A language and environment for statistical computing. . Vienna, Austria. Cooner, W. H., Mosley, B. R., Rutherford, C. L., Beard, J. H., Pond, H. S., Terry, W. J., Igel, T. C., Kidd, D. D., 1990. Prostate-cancer detection in a clinical urological practice by ultrasonography, digital rectal examination and prostate specific antigen. . Journal of Urology 143, 1146-1154.

Crawford, E. D., 2003. Epidemiology of prostate cancer. Urology 62, 3-12.

Davis, C. D., Milner, J. A., 2007. Biomarkers for diet and cancer prevention research: potentials and challenges. Acta Pharmacologica Sinica 28, 1262-1273.

De Jager, P. L., Chibnik, L. B., Cui, J., Reischl, J., Lehr, S., Simon, K. C., Aubin, C., Bauer, D., Heubach, J. F., Sandbrink, R., Tyblova, M., Lelkova, P., Steering committee of the, B. s., Steering committee of the, B. s., Steering committee of the, L. T. F. S., Steering committee of the, C. C. R. s., Havrdova, E., Pohl, C., Horakova, D., Ascherio, A., Hafler, D. A., Karlson, E. W., 2009. Integration of genetic risk factors into a clinical algorithm for multiple sclerosis susceptibility: a weighted genetic risk score. The Lancet. Neurology 8, 1111-1119. Du, M., Yuan, T., Schilter, K. F., Dittmar, R. L., Mackinnon, A., Huang, X., Tschannen, M., Worthey, E., Jacob, H., Xia, S., Gao, J., Tillmans, L., Lu, Y., Liu, P., Thibodeau, S. N., Wang, L., 2015. Prostate cancer risk 
388

locus at $8 \mathrm{q} 24$ as a regulatory hub by physical interactions with multiple genomic loci across the genome. Human Molecular Genetics 24, 154-166.

Eeles, R., Goh, C., Castro, E., Bancroft, E., Guy, M., Al Olama, A. A., Easton, D., Kote-Jarai, Z., 2014. The genetic epidemiology of prostate cancer and its clinical implications. Nature reviews. Urology 11, 18-31. Freedman, L. S., Potischman, N., Kipnis, V., Midthune, D., Schatzkin, A., Thompson, F. E., Troiano, R. P., Prentice, R., Patterson, R., Carroll, R., Subar, A. F., 2006. A comparison of two dietary instruments for evaluating the fat-breast cancer relationship. International Journal of Epidemiology 35, 1011-1021. Ghoussaini, M., Song, H., Koessler, T., Al Olama AA, K.-J. Z., Driver KE, Pooley KA, Ramus SJ, Kjaer SK, Hogdall E, DiCioccio RA, Whittemore AS, Gayther SA, Giles GG, Guy M, Edwards SM, Morrison J, Donovan JL, Hamdy FC, Dearnaley DP, Ardern-Jones AT, Hall AL, O'Brien LT, Gehr-Swain BN, Wilkinson RA, Brown PM, Hopper JL, Neal DE, Pharoah PD, Ponder BA, Eeles RA, Easton DF, Dunning AM; UK Genetic Prostate Cancer Study Collaborators/British Association of Urological Surgeons' Section of Oncology; UK ProtecT Study Collaborators., 2008a. Multiple loci with different cancer specificities within the 8q24 gene desert. J Natl Cancer Inst. 100, 962-966.

Ghoussaini, M., Song, H., Koessler, T., Al Olama, A. A., Kote-Jarai, Z., Driver, K. E., Pooley, K. A., Ramus, S. J., Kjaer, S. K., Hogdall, E., DiCioccio, R. A., Whittemore, A. S., Gayther, S. A., Giles, G. G., Guy, M., Edwards, S. M., Morrison, J., Donovan, J. L., Hamdy, F. C., Dearnaley, D. P., Ardern-Jones, A. T., Hall, A. L., O'Brien, L. T., Gehr-Swain, B. N., Wilkinson, R. A., Brown, P. M., Hopper, J. L., Neal, D. E., Pharoah, P. D. P., Ponder, B. A. J., Eeles, R. A., Easton, D. F., Dunning, A. M., Oncology, f. t. U. G. P. C. S. C. B. A. O. U. S. S. o., Collaborators, t. U. P. S., 2008b. Multiple Loci With Different Cancer Specificities Within the 8q24 Gene Desert. Journal of the National Cancer Institute 100, 962-966.

Giovannucci, E., Liu, Y., Platz, E. A., Stampfer, M. J., Willett, W. C., 2007. Risk factors for prostate cancer incidence and progression in the health professionals follow-up study. International Journal of Cancer 121, 1571-1578.

Glitza, I. C., Lu, G., Shah, R., Bashir, Q., Shah, N., Champlin, R. E., Shah, J., Orlowski, R. Z., Qazilbash, M. H., 2015. Chromosome 8q24.1/c-MYC abnormality: a marker for high-risk myeloma. Leukemia \& Lymphoma 56, 602-607.

Goh, C. L., Schumacher, F. R., Easton, D., Muir, K., Henderson, B., Kote-Jarai, Z., Eeles, R. A., 2012. Genetic variants associated with predisposition to prostate cancer and potential clinical implications. Journal of Internal Medicine 271, 353-365.

Gudmundsson, J., Sulem, P., Gudbjartsson, D. F., Blondal, T., Gylfason, A., Agnarsson, B. A., Benediktsdottir, K. R., Magnusdottir, D. N., Orlygsdottir, G., Jakobsdottir, M., Stacey, S. N., Sigurdsson, A., Wahlfors, T., Tammela, T., Breyer, J. P., McReynolds, K. M., Bradley, K. M., Saez, B., Godino, J., Navarrete, S., Fuertes, F., Murillo, L., Polo, E., Aben, K. K., van Oort, I. M., Suarez, B. K., Helfand, B. T., Kan, D., Zanon, C., Frigge, M. L., Kristjansson, K., Gulcher, J. R., Einarsson, G. V., Jonsson, E., Catalona, W. J., Mayordomo, J. I., Kiemeney, L. A., Smith, J. R., Schleutker, J., Barkardottir, R. B., Kong, A., Thorsteinsdottir, U., Rafnar, T., Stefansson, K., 2009. Genome-wide association and replication studies identify four variants associated with prostate cancer susceptibility. Nature Genetics 41, 1122-1126. Gudmundsson, J., Sulem, P., Manolescu, A., Amundadottir, L. T., Gudbjartsson, D., Helgason, A., Rafnar, T., Bergthorsson, J. T., Agnarsson, B. A., Baker, A., Sigurdsson, A., Benediktsdottir, K. R., Jakobsdottir, M., Xu, J., Blondal, T., Kostic, J., Sun, J., Ghosh, S., Stacey, S. N., Mouy, M., Saemundsdottir, J., Backman, V. M., Kristjansson, K., Tres, A., Partin, A. W., Albers-Akkers, M. T., Godino-Ivan Marcos, J., Walsh, P. C., Swinkels, D. W., Navarrete, S., Isaacs, S. D., Aben, K. K., Graif, T., Cashy, J., Ruiz-Echarri, M., Wiley, K. E., Suarez, B. K., Witjes, J. A., Frigge, M., Ober, C., Jonsson, E., Einarsson, G. V., Mayordomo, J. I., Kiemeney, L. A., Isaacs, W. B., Catalona, W. J., Barkardottir, R. B., Gulcher, J. R., Thorsteinsdottir, U., Kong, A., Stefansson, K., 2007. Genome-wide association study identifies a second prostate cancer susceptibility variant at $8 \mathrm{q} 24$. Nature Genetics 39, 631-637. 
Han, Y., Signorello, L. B., Strom, S. S., Kittles, R. A., Rybicki, B. A., Stanford, J. L., Goodman, P. J., Berndt, S. I., Carpten, J., Casey, G., Chu, L., Conti, D. V., Rand, K. A., Diver, W. R., Hennis, A. J. M., John, E. M., Kibel, A. S., Klein, E. A., Kolb, S., Le Marchand, L., Leske, M. C., Murphy, A. B., Neslund-Dudas, C., Park, J. Y., Pettaway, C., Rebbeck, T. R., Gapstur, S. M., Zheng, S. L., Wu, S.-Y., Witte, J. S., Xu, J., Isaacs, W., Ingles, S. A., Hsing, A., The, P. C., The, E. G.-O. N. C., Easton, D. F., Eeles, R. A., Schumacher, F. R., Chanock, S., Nemesure, B., Blot, W. J., Stram, D. O., Henderson, B. E., Haiman, C. A., 2015. Generalizability of established prostate cancer risk variants in men of African ancestry. International Journal of Cancer 136, 1210-1217.

Hawksworth, D., Ravindranath, L., Chen, Y., Furusato, B., Sesterhenn, I. A., McLeod, D. G., Srivastava, S., Petrovics, G., 2010. Overexpression of C-MYC oncogene in prostate cancer predicts biochemical recurrence. Prostate Cancer and Prostatic Disease 13, 311-315.

Heidenreich, A., Bastian, P. J., Bellmunt, J., Bolla, M., Joniau, S., van der Kwast, T., Mason, M., Matveev, V., Wiegel, T., Zattoni, F., Mottet, N., 2014. EAU Guidelines on Prostate Cancer. Part 1: Screening, Diagnosis, and Local Treatment with Curative Intent-Update 2013. European Urology 65, 124-137. Helfand, B. T., Fought, A. J., Loeb, S., Meeks, J. J., Kan, D., Catalona, W. J., 2010. Genetic Prostate Cancer Risk Assessment: Common Variants in 9 Genomic Regions are Associated With Cumulative Risk. The Journal of Urology 184, 501-505.

Hodgson, F., Obertová, Z., Brown, C., Lawrenson, R., 2012. PSA testing in general practice. J Prim Health Care 204, 199-204.

Karan, D., Kelly, D. L., Rizzino, A., Lin, M.-F., Batra, S. K., 2002. Expression profile of differentiallyregulated genes during progression of androgen-independent growth in human prostate cancer cells. Carcinogenesis 23, 967-976.

Kastler, S., Honold, L., Luedeke, M., Kuefer, R., Möller, P., Hoegel, J., Vogel, W., Maier, C., Assum, G., 2010. POU5F1P1, a putative cancer susceptibility gene, is overexpressed in prostatic carcinoma. The Prostate 70, 666-674.

Kim, S.-T., Cheng, Y., Hsu, F.-C., Jin, T., Kader, A. K., Zheng, S. L., Isaacs, W. B., Xu, J., Sun, J., 2010. Prostate cancer risk-associated variants reported from genome-wide association studies: Meta-analysis and their contribution to genetic Variation. The Prostate 70, 1729-1738.

Lichtenstein, P., Holm, N. V., Verkasalo, P. K., Iliadou, A., Kaprio, J., Koskenvuo, M., Pukkala, E., Skytthe, A., Hemminki, K., 2000. Environmental and Heritable Factors in the Causation of Cancer - Analyses of Cohorts of Twins from Sweden, Denmark, and Finland. New England Journal of Medicine 343, 78-85. Liu, H., Wang, B., Han, C., 2011. Meta-analysis of genome-wide and replication association studies on prostate cancer. The Prostate 71, 209-224.

Meyer, K. B., Maia, A.-T., O'Reilly, M., Ghoussaini, M., Prathalingam, R., Porter-Gill, P., Ambs, S., Prokunina-Olsson, L., Carroll, J., Ponder, B. A. J., 2011. A Functional Variant at a Prostate Cancer Predisposition Locus at 8q24 Is Associated with <italic>PVT1</italic> Expression. PLoS Genetics 7, e1002165.

Neale, R. E., Mineau, G., Whiteman, D. C., Brownbill, P. A., Murphy, M. F., 2005. Childhood and adult cancer in twins: evidence from the Utah genealogy. Cancer Eidemiology, Biomarkers \& Prevention 14, 1236-1240.

NHC, N. H. C., 2004. Prostate Cancer Screening in New Zealand. NHC adviser, vol. 2012, Wellington. Nichols, J., Zevnik, B., Anastassiadis, K., Niwa, H., Klewe-Nebenius, D., Chambers, I., Schöler, H., Smith, A., 1998. Formation of Pluripotent Stem Cells in the Mammalian Embryo Depends on the POU Transcription Factor Oct4. Cell 95, 379-391. Nordström, T., Aly, M., Eklund, M., Egevad, L., Grönberg, H., 2013. A Genetic Score Can Identify Men at High Risk for Prostate Cancer Among Men With Prostate-Specific Antigen of 1-3 ng/ml. European Urology. 
482

483

484

485

486

487

488

489

490

491

492

493

494

495

496

497

498

499

500

501

502

503

504

505

506

507

508

509

510

511

512

513

514

515

516

517

518

519

520

521

522

523

524

525

526

527

528
Okobia, M. N., Zmuda, J. M., Ferrell, R. E., Patrick, A. L., Bunker, C. H., 2011. Chromosome 8q24 variants are associated with prostate cancer risk in a high risk population of African ancestry. The Prostate 71, 1054-1063.

Page, W. F., Braun, M. M., Partin, A. W., Caporaso, N., Walsh, P., 1997. Heredity and prostate cancer: A study of World War II veteran twins. The Prostate 33, 240-245.

Pal, P., Xi, H., Guha, S., Sun, G., Helfand, B. T., Meeks, J. J., Suarez, B. K., Catalona, W. J., Deka, R., 2009.

Common variants in 8 q24 are associated with risk for prostate cancer and tumor aggressiveness in men of European ancestry. The Prostate 69, 1548-1556.

Pomerantz, M. M., Beckwith, C. A., Regan, M. M., Wyman, S. K., Petrovics, G., Chen, Y., Hawksworth, D. J., Schumacher, F. R., Mucci, L., Penney, K. L., Stampfer, M. J., Chan, J. A., Ardlie, K. G., Fritz, B. R., Parkin, R. K., Lin, D. W., Dyke, M., Herman, P., Lee, S., Oh, W. K., Kantoff, P. W., Tewari, M., McLeod, D. G., Srivastava, S., Freedman, M. L., 2009. Evaluation of the 8q24 Prostate Cancer Risk Locus and MYC Expression. Cancer Research 69, 5568-5574.

Ribeiro, F. R., Henrique, R., Martins, A. T., Jerónimo, C., Teixeira, M. R., 2007. Relative Copy Number Gain of MYC in Diagnostic Needle Biopsies is an Independent Prognostic Factor for Prostate Cancer Patients. European Urology 52, 116-125.

Robbins, C., Torres, J. B., Hooker, S., Bonilla, C., Hernandez, W., Candreva, A., Ahaghotu, C., Kittles, R., Carpten, J., 2007. Confirmation study of prostate cancer risk variants at 8q24 in African Americans identifies a novel risk locus. Genome Research 17, 1717-1722.

Severi, G., Hayes, V. M., Padilla, E. J. D., English, D. R., Southey, M. C., Sutherland, R. L., Hopper, J. L., Giles, G. G., 2007. The Common Variant rs1447295 on Chromosome 8q24 and Prostate Cancer Risk: Results from an Australian Population-Based Case-Control Study. Cancer Epidemiology Biomarkers \& Prevention 16, 610-612.

Storey, J. D., 2002. A direct approach to false discovery rates. Journal of the Royal Statistical Society: Series B (Statistical Methodology) 64, 479-498.

Sun, J., Kader, A. K., Hsu, F.-C., Kim, S.-T., Zhu, Y., Turner, A. R., Jin, T., Zhang, Z., Adolfsson, J., Wiklund, F., Zheng, S. L., Isaacs, W. B., Grönberg, H., Xu, J., 2011. Inherited genetic markers discovered to date are able to identify a significant number of men at considerably elevated risk for prostate cancer. The Prostate 71, 421-430.

Teerlink, C., Thibodeau, S., McDonnell, S., Schaid, D., Rinckleb, A., Maier, C., Vogel, W., Cancel-Tassin, G., Egrot, C., Cussenot, O., Foulkes, W., Giles, G., Hopper, J., Severi, G., Eeles, R., Easton, D., Kote-Jarai, Z., Guy, M., Cooney, K., Ray, A., Zuhlke, K., Lange, E., FitzGerald, L., Stanford, J., Ostrander, E., Wiley, K., Isaacs, S., Walsh, P., Isaacs, W., Wahlfors, T., Tammela, T., Schleutker, J., Wiklund, F., Grönberg, H., Emanuelsson, M., Carpten, J., Bailey-Wilson, J., Whittemore, A., Oakley-Girvan, I., Hsieh, C.-L., Catalona, W., Zheng, S. L., Jin, G., Lu, L., Xu, J., Camp, N., Cannon-Albright, L., 2014. Association analysis of 9,560 prostate cancer cases from the International Consortium of Prostate Cancer Genetics confirms the role of reported prostate cancer associated SNPs for familial disease. Hum Genet 133, 347-356.

Thomas, L. P., Dilip, V. J., 1999. The Potential Impact of the Baby-Boom Generation on Substance Abuse Among Elderly Persons. Psychiatric Services 50, 1184-1188.

Wang, Y., Ray, A. M., Johnson, E. K., Zuhlke, K. A., Cooney, K. A., Lange, E. M., 2011. Evidence for an association between prostate cancer and chromosome $8 q 24$ and $10 q 11$ genetic variants in African American men: The flint men's health study. The Prostate 71, 225-231.

Wasserman, N. F., Aneas, I., Nobrega, M. A., 2010. An 8q24 gene desert variant associated with prostate cancer risk confers differential in vivo activity to a MYC enhancer. Genome Research 20, 1191-1197. Wolk, A., 2005. Diet, lifestyle and risk of prostate cancer. Acta Oncologica 44, 277-281.

Wolk, A., 2009. Diet and Physical Activity in Cancer Prevention

Nutrition and Metabolism. In: Mantzoros, C. S. (Ed.). Humana Press, pp. 161-192. 
$529 \mathrm{Xu}$, J., Sun, J., Zheng, S. L., 2013. Prostate cancer risk-associated genetic markers and their potential 530 clinical utility. Asian Journal of Andrology 15, 314-322.

531 Yang, G., Timme, T. L., Frolov, A., Wheeler, T. M., Thompson, T. C., 2005. Combined c-Myc and caveolin5321 expression in human prostate carcinoma predicts prostate carcinoma progression. Cancer 103, 11865331194.

534 Yeager, M., Orr, N., Hayes, R. B., Jacobs, K. B., Kraft, P., Wacholder, S., Minichiello, M. J., Fearnhead, P., 535 Yu, K., Chatterjee, N., Wang, Z., Welch, R., Staats, B. J., Calle, E. E., Feigelson, H. S., Thun, M. J., 536 Rodriguez, C., Albanes, D., Virtamo, J., Weinstein, S., Schumacher, F. R., Giovannucci, E., Willett, W. C., 537 Cancel-Tassin, G., Cussenot, O., Valeri, A., Andriole, G. L., Gelmann, E. P., Tucker, M., Gerhard, D. S., 538 Fraumeni, J. F., Jr., Hoover, R., Hunter, D. J., Chanock, S. J., Thomas, G., 2007. Genome-wide association 539 study of prostate cancer identifies a second risk locus at 8q24. Nature Genetics 39, 645-649.

540 Zhang, Y., Perez, T., Blondin, B., Du, J., Liu, P., Escarzaga, D., Coon, J. S., Morrison, L. E., Pestova, K., 2014.

541 Identification of FISH biomarkers to detect chromosome abnormalities associated with prostate

542 adenocarcinoma in tumour and field effect environment. BioMed Central: Cancer 14, 129. 
547 Table 1. Association of 15 prostate cancer susceptibility single nucleotide polymorphisms, found 548 on $8 \mathrm{q} 24$, with the weighted genetic risk score and assigned weights

\begin{tabular}{|c|c|c|c|c|c|}
\hline SNP & $\begin{array}{l}\text { Tested } \\
\text { Allele }\end{array}$ & $\begin{array}{l}\text { Published } \\
\text { OR }\end{array}$ & $\begin{array}{c}\text { Weight } \\
\text { LN } \\
(\mathrm{OR})\end{array}$ & $\begin{array}{l}\% \text { of total } \\
\text { weight }\end{array}$ & Source \\
\hline rs10086908 & $\mathrm{T}$ & 1.25 from stage 1 & 0.223 & $5.94 \%$ & $\begin{array}{c}\text { (Al Olama et } \\
\text { al., 2009b) }\end{array}$ \\
\hline rs1016342 & $\mathrm{C}$ & 1.26 & 0.231 & $6.15 \%$ & $\begin{array}{c}\text { (Pal et al., } \\
\text { 2009) }\end{array}$ \\
\hline rs1016343 & $\mathrm{T}$ & 1.11 & 0.104 & $2.77 \%$ & $\begin{array}{c}\text { (Al Olama et } \\
\text { al., 2009b) }\end{array}$ \\
\hline rs1378897 & A & $1.26(\mathrm{~ns})$ & 0.231 & $6.15 \%$ & $\begin{array}{l}\text { (Pal et al., } \\
\text { 2009) }\end{array}$ \\
\hline rs1447295 & A & 1.58 & 0.457 & $12.17 \%$ & $\begin{array}{l}\text { (Gudmundsson } \\
\text { et al., 2009) }\end{array}$ \\
\hline rs16901979 & A & 1.8 & 0.588 & $15.65 \%$ & $\begin{array}{l}\text { (Gudmundsson } \\
\text { et al., 2009) }\end{array}$ \\
\hline rs16902094 & G & 1.21 & 0.191 & $5.09 \%$ & $\begin{array}{l}\text { (Gudmundsson } \\
\text { et al., 2009) }\end{array}$ \\
\hline rs4242382 & A & 1.39 & 0.329 & $8.76 \%$ & $\begin{array}{c}\text { (Teerlink et } \\
\text { al., 2014) }\end{array}$ \\
\hline rs445114 & $\mathrm{T}$ & 1.14 & 0.131 & $3.49 \%$ & $\begin{array}{l}\text { (Gudmundsson } \\
\text { et al., 2009) }\end{array}$ \\
\hline rs620861 & $\mathrm{C}$ & $\begin{array}{l}1.11 \text { from stage } 1 \\
(\mathrm{~ns})\end{array}$ & 0.104 & $2.77 \%$ & $\begin{array}{l}\text { (Al Olama et } \\
\text { al., 2009b) }\end{array}$ \\
\hline rs6470494 & $\mathrm{T}$ & $1.00^{1}$ & 0.0 & $0.0 \%$ & $\begin{array}{c}\text { (Pal et al., } \\
\text { 2009) }\end{array}$ \\
\hline rs6470517 & A & 1.58 & 0.457 & $12.17 \%$ & $\begin{array}{l}\text { (Pal et al., } \\
\text { 2009) }\end{array}$ \\
\hline rs6983267 & $\mathrm{G}$ & 1.19 & 0.174 & $4.63 \%$ & $\begin{array}{l}\text { (Al Olama et } \\
\text { al., 2009b) }\end{array}$ \\
\hline rs7000448 & $\mathrm{T}$ & 1.23 & 0.207 & $5.51 \%$ & $\begin{array}{c}\text { (Ghoussaini et } \\
\text { al., 2008b) }\end{array}$ \\
\hline rs871135 & $\mathrm{G}$ & 1.39 & 0.329 & $8.76 \%$ & $\begin{array}{c}\text { (Pal et al., } \\
\text { 2009) }\end{array}$ \\
\hline
\end{tabular}

$549{ }^{1}$ OR from Pal et al (Pal et al., 2009) was 1.00. In Liu et al (Liu et al., 2011) a meta-analysis was 550 carried out with the following results: GWAS meta-analysis OR=1.14; Replication meta-analysis $551 \mathrm{OR}=1.00$; All meta-analyses $\mathrm{OR}=1.14$. It was decided to use the $\mathrm{OR}$ value from the Replication 552 meta-analysis.

$553 \mathrm{SNP}=$ single nucleotide polymorphism; $\mathrm{ns}=$ not significant; $\mathrm{OR}=$ odds ratio; $\mathrm{LN}=$ natural $\log$ 
557 Table 2. Lifestyle and clinical characteristics of the study participants

\begin{tabular}{|c|c|c|c|c|c|}
\hline Phenotypic variables & Status & $\begin{array}{l}\text { Malignant } \\
{ }^{1}(\mathrm{~N}=489)\end{array}$ & $\begin{array}{c}\text { Control } \\
{ }^{1}(\mathrm{~N}=427)\end{array}$ & $\begin{array}{c}\text { OR } \\
(95 \% \mathrm{CI})\end{array}$ & $\mathrm{P}$ value \\
\hline \multirow[t]{3}{*}{ Smoking status: N (\%) } & $\begin{array}{l}\text { Ever } \\
\text { smoked(Current/Former) }\end{array}$ & $227(64.5)$ & $144(37.0)$ & $2.28(1.62-3.21)$ & $2.32 \mathrm{e}-06$ \\
\hline & Never & $125(35.5)$ & $245(63.0)$ & 1.00 & \\
\hline & & 137 & 38 & & \\
\hline \multirow[t]{2}{*}{ Alcohol: N (\%) } & Yes & $265(75.3)$ & $338(86.4)$ & $0.57(0.37-0.90)$ & 0.0147 \\
\hline & No & $87(24.7)$ & $53(13.6)$ & 1.00 & \\
\hline Missing Data ${ }^{2}$ & & 137 & 38 & & \\
\hline $\begin{array}{l}\text { Age at Diagnosis: } \\
\text { Mean (SD) }\end{array}$ & & $65.8(8.2)$ & $53.1(13.6)$ & $1.10(1.08-1.12)$ & $9.88 \mathrm{e}-27$ \\
\hline BMI: Mean (SD) & & $27.3(3.8)$ & $26.8(3.7)$ & $1.02(0.98-1.07)$ & 0.2934 \\
\hline
\end{tabular}

558

559

560

561

$\mathrm{N}=$ sample $\operatorname{size}^{1}$ (complete data set for all for variables with no missing data); $\mathrm{OR}=$ odds ratio; $\mathrm{CI}=$ confidence interval; $\mathrm{SD}=$ standard deviation; $\mathrm{BMI}=$ body mass index. "Yes" $=1$ or more alcoholic units a week. Missing Data $^{2}=$ at least one missing datum point amongst the four variables. 
562 Table 3. Single nucleotide polymorphisms and known genes or pseudo genes in 8q24, listed by 563 position on chromosome 8 (HapMap Genome Build 37.3)

564

\begin{tabular}{|c|c|c|c|c|}
\hline $\mathrm{SNP} /$ gene & Genotype & Chromosome Position & $\begin{array}{l}\text { SNP to } \\
\text { Chromosome }\end{array}$ & $\begin{array}{l}\text { Sequence } \\
\text { Length }\end{array}$ \\
\hline FAM84B & & $\begin{array}{r}127564683- \\
127570711\end{array}$ & & 6029 \\
\hline rs 10086908 & $\mathrm{C} / \mathrm{T}$ & 128011937 & Fwd & \\
\hline $\begin{array}{l}\text { PROSTATE } \\
\text { CANCERT1 }\end{array}$ & & $\begin{array}{r}128025399 \\
128033259\end{array}$ & & 7861 \\
\hline rs6470494 & $\mathrm{C} / \mathrm{T}$ & 128087904 & Fwd & \\
\hline rs 1016342 & $\mathrm{C} / \mathrm{T}$ & 128092455 & Fwd & \\
\hline rs1016343 & $\mathrm{C} / \mathrm{T}$ & 128093297 & Fwd & \\
\hline rs1378897 & $\mathrm{A} / \mathrm{G}$ & 128122659 & Fwd & \\
\hline rs 16901979 & $\mathrm{~A} / \mathrm{C}$ & 128124916 & Fwd & \\
\hline rs16902094 & $\mathrm{A} / \mathrm{G}$ & 128320346 & Fwd & \\
\hline rs445114 & $\mathrm{C} / \mathrm{T}$ & 128323181 & Fwd & \\
\hline rs620861 & $\mathrm{C} / \mathrm{T}$ & 128335673 & Rev & \\
\hline rs6983267 & $\mathrm{G} / \mathrm{T}$ & 128413305 & Fwd & \\
\hline rs871135 & $\mathrm{G} / \mathrm{T}$ & 128426393 & Fwd & \\
\hline POU5F1B & & $\begin{array}{r}128427857- \\
128429455\end{array}$ & & 1599 \\
\hline rs7000448 & $\mathrm{C} / \mathrm{T}$ & 128441170 & Fwd & \\
\hline rs6470517 & $\mathrm{A} / \mathrm{G}$ & 128460404 & Fwd & \\
\hline rs1447295 & $\mathrm{A} / \mathrm{C}$ & 128485038 & Fwd & \\
\hline rs4242382 & $\mathrm{A} / \mathrm{G}$ & 128517573 & Fwd & \\
\hline MYC & & $\begin{array}{r}128748315- \\
128753680\end{array}$ & & 5366 \\
\hline PVT1 & & $\begin{array}{r}128902874- \\
129113499 \\
\end{array}$ & & 210626 \\
\hline & & & & \\
\hline
\end{tabular}

$\mathrm{SNP}=$ single nucleotide polymorphism; $F A M 84 B=$ family with sequence similarity 84 , member $B$;

566 PROSTATE CANCERT1=prostate cancer associated transcript 1; POU5F1B=POU class 5

567 homeobox 1B; MYC=v-myc avian myelocytomatosis viral oncogene homolog; PCT1=

568 phosphocholine cytidylyltransferase 1. 
569 Table 4. Association of 15 prostate cancer susceptibility single nucleotide polymorphisms, found in 8q24, 570 with risk of prostate cancer (after adjustment for age, alcohol consumption and smoking status)

\begin{tabular}{|c|c|c|c|c|c|c|}
\hline & & Tested Allele & $\mathrm{N}$ & OR $(95 \% \mathrm{Cl})$ & $p$ value & q value \\
\hline \multirow[t]{2}{*}{ rs10086908 } & Malignant & $\mathrm{T}$ & 364 & $1.64(1.25-2.15)$ & 3.03E-04 & 0.0040 \\
\hline & Control & & 390 & 1.00 & & \\
\hline \multirow[t]{2}{*}{ rs16901979 } & Malignant & A & 368 & $2.58(1.48-4.5)$ & 8.42E-04 & 0.0056 \\
\hline & Control & & 388 & 1.00 & & \\
\hline \multirow[t]{2}{*}{ rs1447295 } & Malignant & $A$ & 362 & $1.70(1.18-2.46)$ & 0.0047 & 0.0209 \\
\hline & Control & & 389 & 1.00 & & \\
\hline \multirow[t]{2}{*}{ rs4242382 } & Malignant & A & 362 & $1.60(1.10-2.33)$ & 0.0133 & 0.0444 \\
\hline & Control & & 388 & 1.00 & & \\
\hline \multirow[t]{2}{*}{ rs16902094 } & Malignant & G & 366 & $1.31(1.03-1.65)$ & 0.0260 & 0.0695 \\
\hline & Control & & 387 & 1.00 & & \\
\hline \multirow[t]{2}{*}{ rs1016342 } & Malignant & $\mathrm{C}$ & 364 & $1.41(1.02-1.95)$ & 0.0369 & 0.0822 \\
\hline & Control & & 389 & 1.00 & & \\
\hline \multirow[t]{2}{*}{ rs445114 } & Malignant & $\mathrm{T}$ & 353 & $1.19(0.93-1.54)$ & 0.1729 & 0.3300 \\
\hline & Control & & 392 & 1.00 & & \\
\hline \multirow[t]{2}{*}{ rs620861 } & Malignant & C & 370 & $1.14(0.90-1.46)$ & 0.2798 & 0.3965 \\
\hline & Control & & 369 & 1.00 & & \\
\hline \multirow[t]{2}{*}{ rs6983267 } & Malignant & G & 362 & $1.14(0.90-1.46)$ & 0.2803 & 0.3965 \\
\hline & Control & & 391 & 1.00 & & \\
\hline \multirow[t]{2}{*}{ rs871135 } & Malignant & G & 355 & $1.14(0.89-1.44)$ & 0.2967 & 0.3965 \\
\hline & Control & & 390 & 1.00 & & \\
\hline \multirow[t]{2}{*}{ rs7000448 } & Malignant & $\mathrm{T}$ & 360 & $0.92(0.72-1.18)$ & 0.5032 & 0.6113 \\
\hline & Control & & 386 & 1.00 & & \\
\hline \multirow[t]{2}{*}{ rs1016343 } & Malignant & $\mathrm{T}$ & 345 & $1.06(0.79-1.41)$ & 0.7172 & 0.7986 \\
\hline & Control & & 398 & 1.00 & & \\
\hline \multirow[t]{2}{*}{ rs6470494 } & Malignant & $\mathrm{T}$ & 370 & $1.04(0.81-1.34)$ & 0.7794 & 0.8004 \\
\hline & Control & & 390 & 1.00 & & \\
\hline \multirow[t]{2}{*}{ rs1378897 } & Malignant & $A$ & 372 & $1.05(0.64-1.73)$ & 0.8386 & 0.8004 \\
\hline & Control & & 380 & 1.00 & & \\
\hline \multirow[t]{2}{*}{ rs6470517 } & Malignant & $A$ & 337 & $1.00(0.68-1.45)$ & 0.9836 & 0.8762 \\
\hline & Control & & 391 & 1.00 & & \\
\hline \multirow[t]{2}{*}{ wGRS15 } & Malignant & & 283 & $1.10(1.04-1.15)$ & $3.14 \mathrm{E}-04$ & \\
\hline & Control & & 341 & 1.00 & & \\
\hline
\end{tabular}

571

572 Bold text indicates statistically significant values.

$573 \mathrm{~N}=$ sample size; $\mathrm{OR}=$ odds ratio; $\mathrm{CI}=$ confidence interval; wGRS15=weighted genetic risk score

574 based on 15 single nucleotide polymorphisms

575 Q-value $=\mathrm{p}$-value after correction for multiple testing (Storey, 2002) 


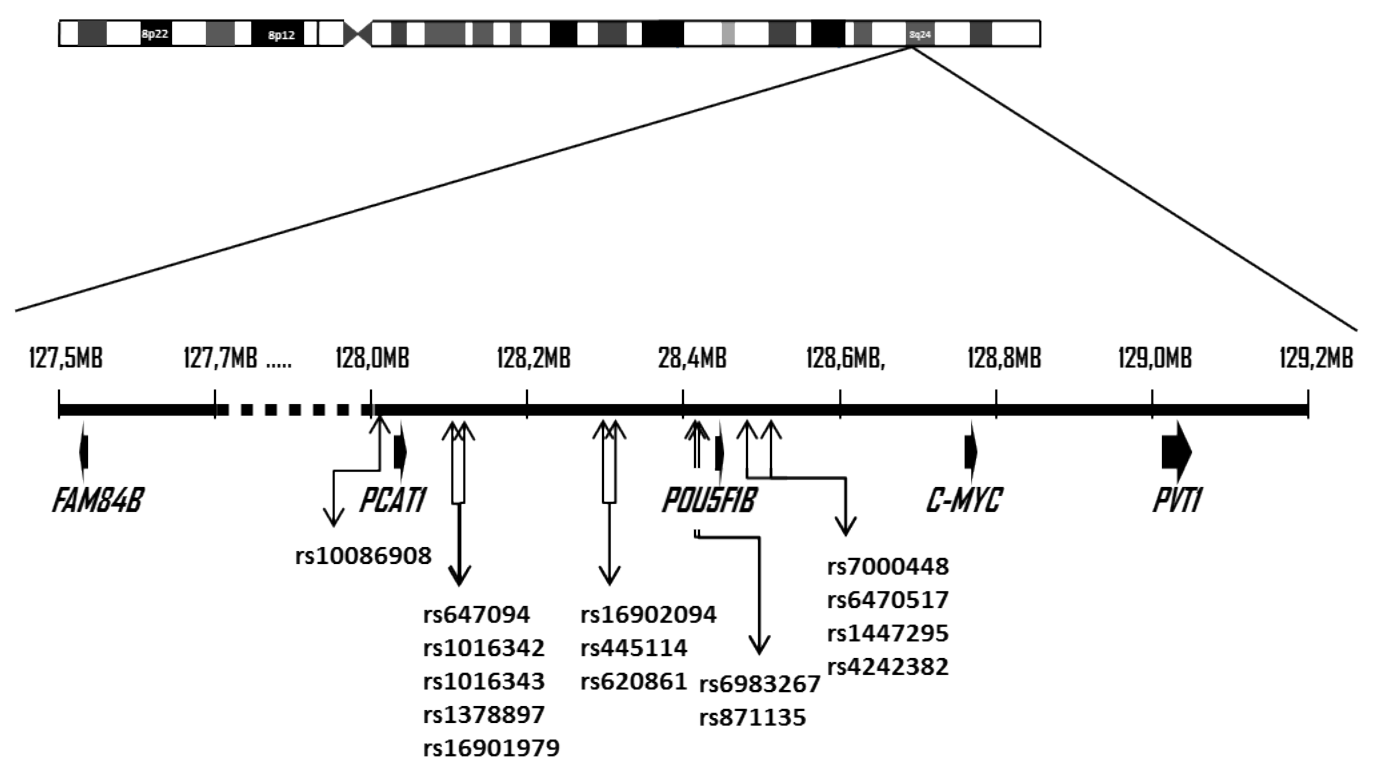

576

578

579

580

581

582

583
Figure 1. Localisation of single nucleotide polymorphisms on 8q24.21 which were tested in this study and show association with prostate cancer risk and/or progression. C-MYC and FAM84B are known genes on $8 \mathrm{q} 24$ which border the so-called gene desert. The exact position of the SNPs can be found in Table 3. (Figure adapted from (Kastler et al., 2010)). 


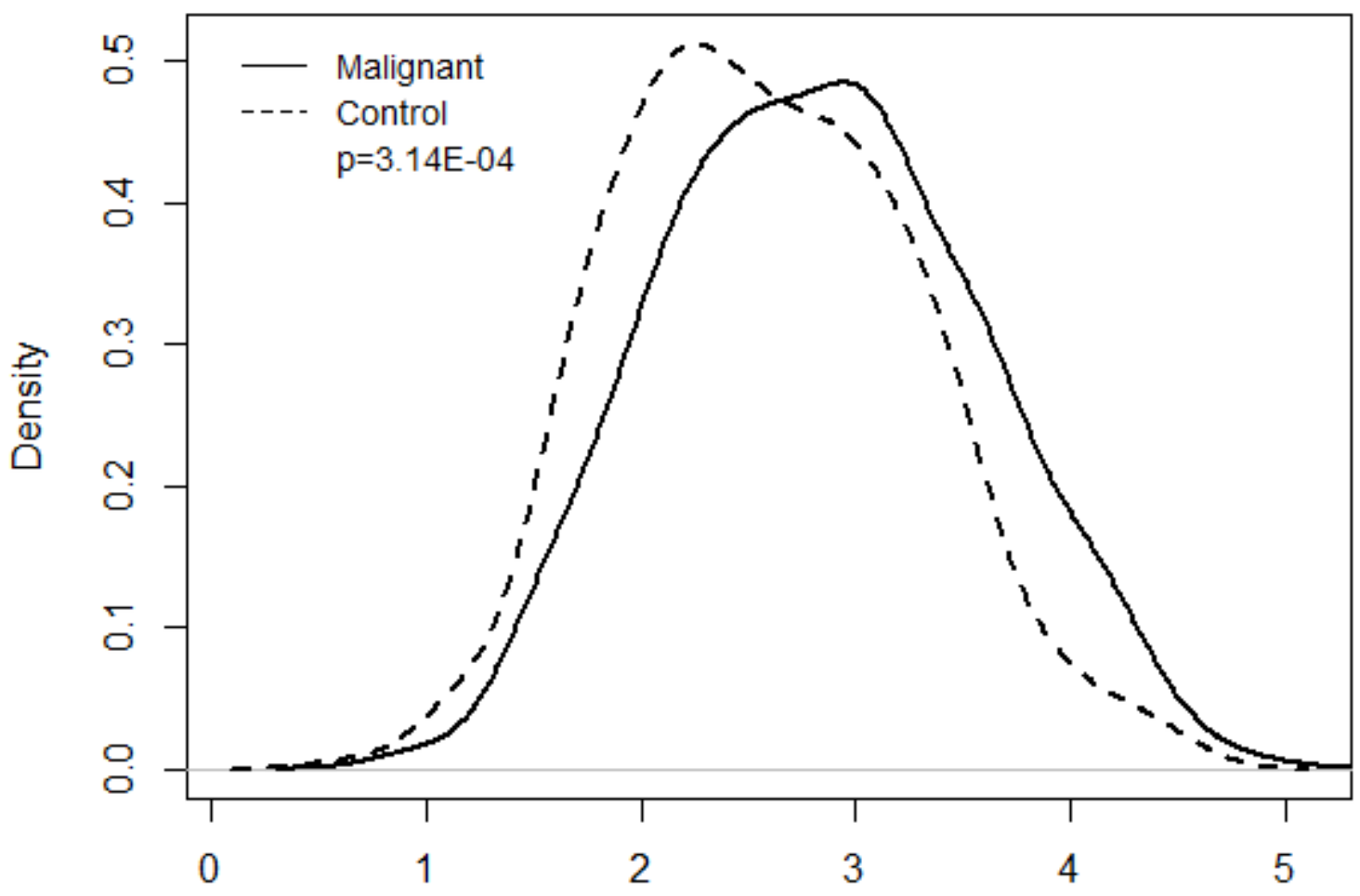

Figure 2. Presentation of weighted genetic risk score differences using 15 genetic 


\section{Table 1 (on next page)}

Association of SNPs with prostate cancer - from the literature. 


\begin{tabular}{|c|c|c|c|c|c|}
\hline SNP & $\begin{array}{l}\text { Tested } \\
\text { Allele }\end{array}$ & $\begin{array}{l}\text { Published } \\
\text { OR }\end{array}$ & $\begin{array}{c}\text { Weight } \\
\text { LN } \\
\text { (OR) }\end{array}$ & $\begin{array}{c}\% \text { of total } \\
\text { weight }\end{array}$ & Source \\
\hline rs10086908 & $\mathrm{T}$ & 1.25 from stage 1 & 0.223 & $5.94 \%$ & $\begin{array}{l}\text { (Al Olama et } \\
\text { al., 2009b) }\end{array}$ \\
\hline rs1016342 & $\mathrm{C}$ & 1.26 & 0.231 & $6.15 \%$ & $\begin{array}{l}\text { (Pal et al., } \\
\text { 2009) }\end{array}$ \\
\hline rs1016343 & $\mathrm{T}$ & 1.11 & 0.104 & $2.77 \%$ & $\begin{array}{l}\text { (Al Olama et } \\
\text { al., 2009b) }\end{array}$ \\
\hline rs1378897 & A & $1.26(\mathrm{~ns})$ & 0.231 & $6.15 \%$ & $\begin{array}{l}\text { (Pal et al., } \\
\text { 2009) }\end{array}$ \\
\hline rs1447295 & A & 1.58 & 0.457 & $12.17 \%$ & $\begin{array}{l}\text { (Gudmundsson } \\
\text { et al., 2009) }\end{array}$ \\
\hline rs16901979 & A & 1.8 & 0.588 & $15.65 \%$ & $\begin{array}{l}\text { (Gudmundsson } \\
\text { et al., 2009) }\end{array}$ \\
\hline rs16902094 & G & 1.21 & 0.191 & $5.09 \%$ & $\begin{array}{l}\text { (Gudmundsson } \\
\text { et al., 2009) }\end{array}$ \\
\hline rs4242382 & A & 1.39 & 0.329 & $8.76 \%$ & $\begin{array}{l}\text { (Teerlink et } \\
\text { al., 2014) }\end{array}$ \\
\hline rs445114 & $\mathrm{T}$ & 1.14 & 0.131 & $3.49 \%$ & $\begin{array}{l}\text { (Gudmundsson } \\
\text { et al., 2009) }\end{array}$ \\
\hline rs620861 & $\mathrm{C}$ & $\begin{array}{l}1.11 \text { from stage } 1 \\
(\mathrm{~ns})\end{array}$ & 0.104 & $2.77 \%$ & $\begin{array}{l}\text { (Al Olama et } \\
\text { al., 2009b) }\end{array}$ \\
\hline rs6470494 & $\mathrm{T}$ & $1.00^{1}$ & 0.0 & $0.0 \%$ & $\begin{array}{l}\text { (Pal et al., } \\
\text { 2009) }\end{array}$ \\
\hline rs6470517 & A & 1.58 & 0.457 & $12.17 \%$ & $\begin{array}{l}\text { (Pal et al., } \\
\text { 2009) }\end{array}$ \\
\hline rs6983267 & G & 1.19 & 0.174 & $4.63 \%$ & $\begin{array}{l}\text { (Al Olama et } \\
\text { al., 2009b) }\end{array}$ \\
\hline rs7000448 & $\mathrm{T}$ & 1.23 & 0.207 & $5.51 \%$ & $\begin{array}{l}\text { (Ghoussaini et } \\
\text { al., 2008b) }\end{array}$ \\
\hline rs871135 & G & 1.39 & 0.329 & $8.76 \%$ & $\begin{array}{l}\text { (Pal et al., } \\
\text { 2009) }\end{array}$ \\
\hline
\end{tabular}

1 OR from Pal et al (Pal et al., 2009) was 1.00. In Liu et al (Liu et al., 2011) a meta-analysis was 2 carried out with the following results: GWAS meta-analysis $\mathrm{OR}=1.14$; Replication meta-analysis $3 \mathrm{OR}=1.00$; All meta-analyses $\mathrm{OR}=1.14$. It was decided to use the $\mathrm{OR}$ value from the Replication 4 meta-analysis.

$5 \mathrm{SNP}=$ single nucleotide polymorphism; ns=not significant; $\mathrm{OR}=$ odds ratio; $\mathrm{LN}=$ natural $\log$ 6 
Table 2 (on next page)

Lifestyle and clinical characteristics 


\begin{tabular}{|c|c|c|c|c|c|}
\hline Phenotypic variables & Status & $\begin{array}{l}\text { Malignant } \\
{ }^{1}(\mathrm{~N}=489)\end{array}$ & $\begin{array}{c}\text { Control } \\
{ }^{1}(\mathrm{~N}=427)\end{array}$ & $\begin{array}{c}\text { OR } \\
(95 \% \mathrm{CI})\end{array}$ & $\mathrm{P}$ value \\
\hline \multirow[t]{2}{*}{ Smoking status: N (\%) } & $\begin{array}{c}\text { Ever smoked } \\
\text { (Current/ } \\
\text { Former) }\end{array}$ & $\begin{array}{c}227 \\
(64.5)\end{array}$ & $144(37.0)$ & $\begin{array}{c}2.28 \\
(1.62-3.21)\end{array}$ & $2.32 \mathrm{e}-06$ \\
\hline & Never & $\begin{array}{c}125 \\
(35.5)\end{array}$ & $245(63.0)$ & 1.00 & \\
\hline \multirow[t]{2}{*}{ Alcohol: N (\%) } & Yes & $\begin{array}{l}265 \\
(75.3)\end{array}$ & $338(86.4)$ & $\begin{array}{c}0.57 \\
(0.37-0.90)\end{array}$ & 0.0147 \\
\hline & No & $\begin{array}{c}87 \\
(24.7)\end{array}$ & $53(13.6)$ & 1.00 & \\
\hline Missing Data ${ }^{2}$ & & 137 & 38 & & \\
\hline $\begin{array}{l}\text { Age at Diagnosis: } \\
\text { Mean (SD) }\end{array}$ & & $\begin{array}{l}65.8 \\
(8.2)\end{array}$ & $53.1(13.6)$ & $\begin{array}{c}1.10 \\
(1.08-1.12)\end{array}$ & $9.88 \mathrm{e}-27$ \\
\hline BMI: Mean (SD) & & $\begin{array}{l}27.3 \\
(3.8)\end{array}$ & $26.8(3.7)$ & $\begin{array}{c}1.02 \\
(0.98-1.07)\end{array}$ & 0.2934 \\
\hline
\end{tabular}

$\mathrm{N}=$ sample size ${ }^{1}$ (complete data set for all variables with no missing data); $\mathrm{OR}=$ odds ratio; $\mathrm{CI}=$ confidence interval; $\mathrm{SD}=$ standard deviation; $\mathrm{BMI}=$ body mass index. "Yes" $=1$ or more alcoholic units a week.

4 Missing Data $^{2}=$ at least one missing datum point amongst the four variables. 
Table 3 (on next page)

SNPs and gene positions on $8 q 24$ 


\begin{tabular}{|c|c|c|c|c|}
\hline SNP/gene & Genotype & Chromosome Position & $\begin{array}{l}\text { SNP to } \\
\text { Chromosome }\end{array}$ & $\begin{array}{l}\text { Sequence } \\
\text { Length }\end{array}$ \\
\hline FAM84B & & $\begin{array}{r}127564683- \\
127570711 \\
\end{array}$ & & 6029 \\
\hline rs 10086908 & $\mathrm{C} / \mathrm{T}$ & 128011937 & Fwd & \\
\hline $\begin{array}{l}\text { PROSTATE } \\
\text { CANCERT1 }\end{array}$ & & $\begin{array}{r}128025399- \\
128033259\end{array}$ & & 7861 \\
\hline rs6470494 & $\mathrm{C} / \mathrm{T}$ & 128087904 & Fwd & \\
\hline rs 1016342 & $\mathrm{C} / \mathrm{T}$ & 128092455 & Fwd & \\
\hline rs 1016343 & $\mathrm{C} / \mathrm{T}$ & 128093297 & Fwd & \\
\hline rs1378897 & $\mathrm{A} / \mathrm{G}$ & 128122659 & Fwd & \\
\hline rs16901979 & $\mathrm{A} / \mathrm{C}$ & 128124916 & Fwd & \\
\hline rs16902094 & $\mathrm{A} / \mathrm{G}$ & 128320346 & Fwd & \\
\hline rs445114 & $\mathrm{C} / \mathrm{T}$ & 128323181 & Fwd & \\
\hline rs620861 & $\mathrm{C} / \mathrm{T}$ & 128335673 & Rev & \\
\hline rs6983267 & $\mathrm{G} / \mathrm{T}$ & 128413305 & Fwd & \\
\hline rs871135 & $\mathrm{G} / \mathrm{T}$ & 128426393 & Fwd & \\
\hline POU5F1B & & $\begin{array}{r}128427857- \\
128429455\end{array}$ & & 1599 \\
\hline rs7000448 & $\mathrm{C} / \mathrm{T}$ & 128441170 & Fwd & \\
\hline rs6470517 & $\mathrm{A} / \mathrm{G}$ & 128460404 & Fwd & \\
\hline rs 1447295 & $\mathrm{~A} / \mathrm{C}$ & 128485038 & Fwd & \\
\hline rs 4242382 & $\mathrm{~A} / \mathrm{G}$ & 128517573 & Fwd & \\
\hline MYC & & $\begin{array}{r}28748315- \\
128753680 \\
\end{array}$ & & 5366 \\
\hline PVT1 & & $\begin{array}{r}128902874- \\
129113499 \\
\end{array}$ & & 210626 \\
\hline
\end{tabular}

$1 \mathrm{SNP}=$ single nucleotide polymorphism; FAM $84 B=$ family with sequence similarity 84 , member $B$;

2 PROSTATE CANCERT1= prostate cancer associated transcript 1; POU5F1B=POU class 5

3 homeobox 1B; MYC=v-myc avian myelocytomatosis viral oncogene homolog; PCT1=

4 phosphocholine cytidylyltransferase 1. 


\section{Table 4(on next page)}

Genotype and prostate cancer risk 


\begin{tabular}{|c|c|c|c|c|c|c|}
\hline SNP code & Status & Tested Allele & $\mathrm{N}$ & OR $(95 \% \mathrm{Cl})$ & $p$ value & q value \\
\hline \multirow[t]{2}{*}{ rs10086908 } & Malignant & $\mathrm{T}$ & 364 & $1.64(1.25-2.15)$ & 3.03E-04 & 0.0040 \\
\hline & Control & & 390 & 1.00 & & \\
\hline \multirow[t]{2}{*}{ rs16901979 } & Malignant & $A$ & 368 & $2.58(1.48-4.5)$ & 8.42E-04 & 0.0056 \\
\hline & Control & & 388 & 1.00 & & \\
\hline \multirow[t]{2}{*}{ rs1447295 } & Malignant & $A$ & 362 & $1.70(1.18-2.46)$ & 0.0047 & 0.0209 \\
\hline & Control & & 389 & 1.00 & & \\
\hline \multirow[t]{2}{*}{ rs4242382 } & Malignant & $A$ & 362 & $1.60(1.10-2.33)$ & 0.0133 & 0.0444 \\
\hline & Control & & 388 & 1.00 & & \\
\hline \multirow[t]{2}{*}{ rs16902094 } & Malignant & G & 366 & $1.31(1.03-1.65)$ & 0.0260 & 0.0695 \\
\hline & Control & & 387 & 1.00 & & \\
\hline \multirow[t]{2}{*}{ rs1016342 } & Malignant & $\mathrm{C}$ & 364 & $1.41(1.02-1.95)$ & 0.0369 & 0.0822 \\
\hline & Control & & 389 & 1.00 & & \\
\hline \multirow[t]{2}{*}{ rs445114 } & Malignant & $\mathrm{T}$ & 353 & $1.19(0.93-1.54)$ & 0.1729 & 0.3300 \\
\hline & Control & & 392 & 1.00 & & \\
\hline \multirow[t]{2}{*}{ rs620861 } & Malignant & $\mathrm{C}$ & 370 & $1.14(0.90-1.46)$ & 0.2798 & 0.3965 \\
\hline & Control & & 369 & 1.00 & & \\
\hline \multirow[t]{2}{*}{ rs6983267 } & Malignant & G & 362 & $1.14(0.90-1.46)$ & 0.2803 & 0.3965 \\
\hline & Control & & 391 & 1.00 & & \\
\hline \multirow[t]{2}{*}{ rs871135 } & Malignant & G & 355 & $1.14(0.89-1.44)$ & 0.2967 & 0.3965 \\
\hline & Control & & 390 & 1.00 & & \\
\hline \multirow[t]{2}{*}{ rs7000448 } & Malignant & $\mathrm{T}$ & 360 & $0.92(0.72-1.18)$ & 0.5032 & 0.6113 \\
\hline & Control & & 386 & 1.00 & & \\
\hline \multirow[t]{2}{*}{ rs1016343 } & Malignant & $\mathrm{T}$ & 345 & $1.06(0.79-1.41)$ & 0.7172 & 0.7986 \\
\hline & Control & & 398 & 1.00 & & \\
\hline \multirow[t]{2}{*}{ rs6470494 } & Malignant & $\mathrm{T}$ & 370 & $1.04(0.81-1.34)$ & 0.7794 & 0.8004 \\
\hline & Control & & 390 & 1.00 & & \\
\hline \multirow[t]{2}{*}{ rs1378897 } & Malignant & $A$ & 372 & $1.05(0.64-1.73)$ & 0.8386 & 0.8004 \\
\hline & Control & & 380 & 1.00 & & \\
\hline \multirow[t]{2}{*}{ rs6470517 } & Malignant & $A$ & 337 & $1.00(0.68-1.45)$ & 0.9836 & 0.8762 \\
\hline & Control & & 391 & 1.00 & & \\
\hline \multirow[t]{2}{*}{ wGRS15 } & Malignant & & 283 & $1.10(1.04-1.15)$ & 3.14E-04 & \\
\hline & Control & & 341 & 1.00 & & \\
\hline
\end{tabular}

1 Bold text indicates statistically significant values.

$2 \mathrm{SNP}=$ single nucleotide polymorphism; $\mathrm{N}=$ sample size; $\mathrm{OR}=$ odds ratio; $\mathrm{CI}=$ confidence interval;

3 wGRS15=weighted genetic risk score based on 15 single nucleotide polymorphisms

4 Q-value $=\mathrm{p}$-value after correction for multiple testing (Storey, 2002) 
Figure 1 (on next page)

Schematic of $8 q 24$ chromosomal region 
Chromosome 8

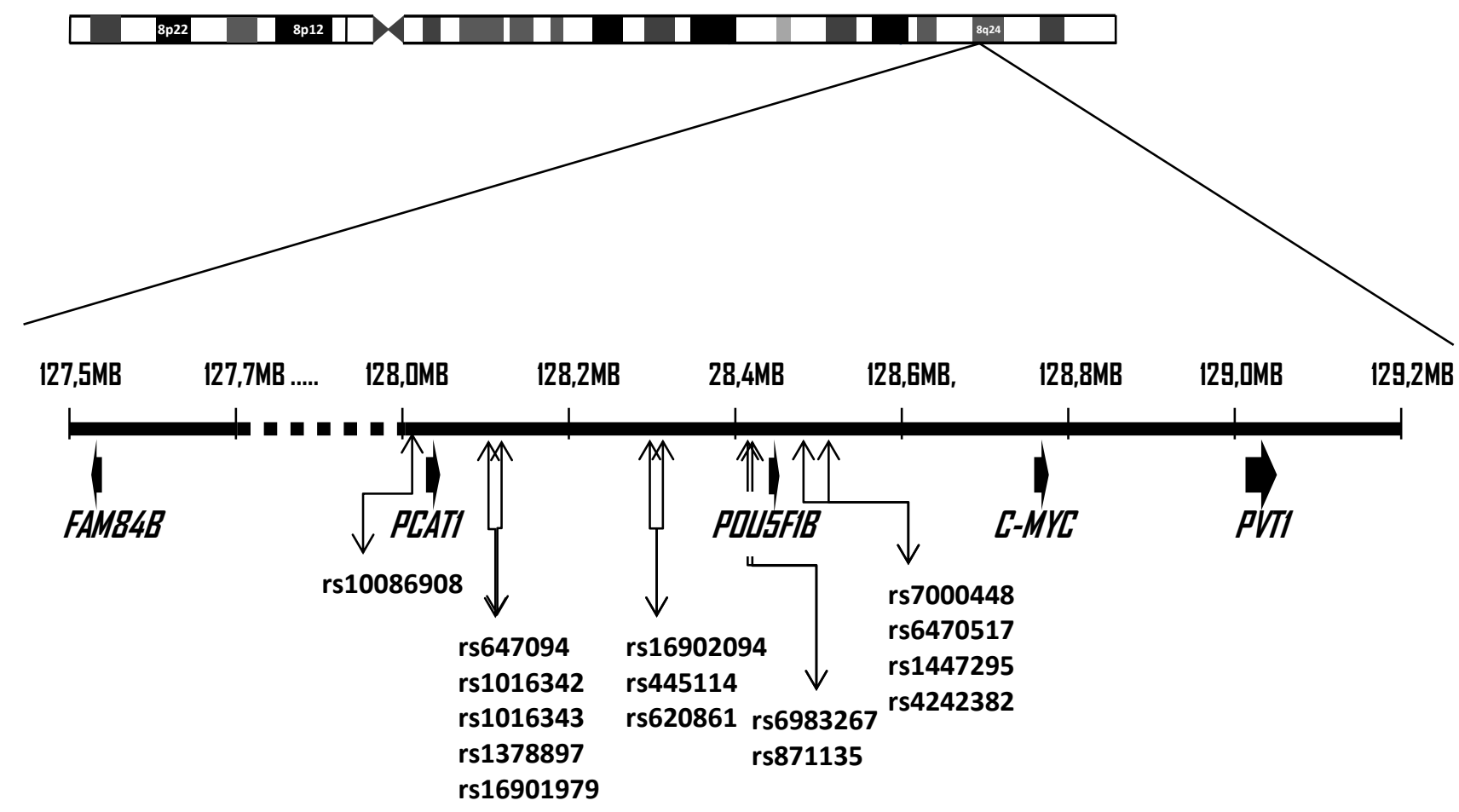


Figure 2 (on next page)

Genetic risk score 


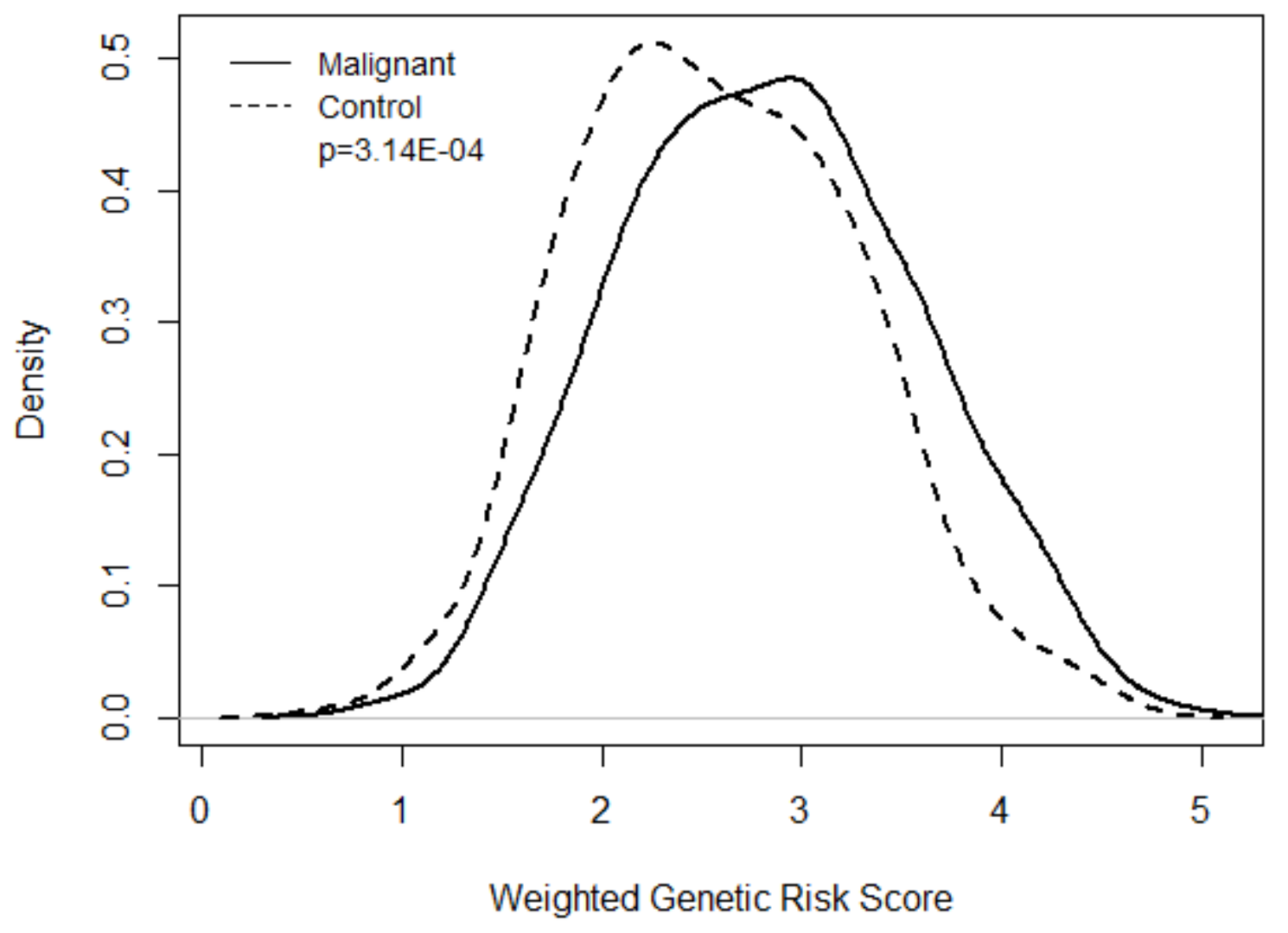

